\title{
Nigerian Defence Academy Shooting Zone: Soil Speciation of the Kwanar-Doya Military Shooting Range, Kachia, Kaduna State, Nigeria
}

\author{
Jonathan Maduka Nwaedozie, Femi Emmanuel Awe, and Ifeanyi Charles Aghanwa
}

\begin{abstract}
The speciation of toxic metals of $\mathrm{Co}, \mathrm{Cr}, \mathrm{Cu}, \mathrm{Mn}$, $\mathrm{Pb}, \mathrm{Zn}, \mathrm{Ni}$ and As in Kwanar - Doya Shooting site of the Nigerian Army, Military Training, Base Camp, Kachia, Kaduna State, Nigeria was investigated. The soil physico-chemical parameters, total metal content and sequential extraction methods were determined in duplicates using standard methods. The $\mathrm{pH}$ ranged from 3.93-4.51, showing the high acidity of the soil and electro -conductivity gave a mean value of $0.11 \mathrm{~ms} / \mathrm{cm}$ showing the poor nutrient value of the soil). While the mean total metals values were Zinc: $28.94 \mathrm{mg} / \mathrm{kg}$, Nickel: $13.45 \mathrm{mg} / \mathrm{kg}$, Manganese: 78: $12 \mathrm{mg} / \mathrm{kg}$, Lead: $40.6 \mathrm{mg} / \mathrm{kg}$, Arsenic: 305 $\mathrm{mg} / \mathrm{kg}$, Chromium: $49.32 \mathrm{mg} / \mathrm{kg}$, Cobalt: $162: 50 \mathrm{mg} / \mathrm{kg}$ and copper: $7.3 \mathrm{mg} / \mathrm{kg}$. All the metals were above the W.H.O permissible limit for toxic metals in soils except Zinc and Nickel. The sequential partitioning and distribution and variation of toxic metals in the various fractions of the Nigerian Defence Academy Shooting Range soil were in the following order: Cobalt: Residual > Bound to carbonate > Exchangeable > Organic $>\mathrm{Fe}-\mathrm{Mn}$ Oxide Arsenic: $\mathrm{Fe}-\mathrm{Mn}$ Oxide $>$ Bound to carbonate > Residual > Organic > Chromium: Bound to carbonate $>$ Exchangeable $>\mathrm{Fe}-\mathrm{Mn}$ Oxide $>$ Organic $>$ Residual. Nickel: $\mathrm{Fe}-$ Mn Oxide $>$ Exchangeable $>$ Bound to carbonate $>$ Residual $>$ Organic. Manganese: Residual $>$ Fe Mn Oxide > Bound to carbonate $>$ Organic $>$ Exchangeable. Lead: Residual $>$ Organic $>$ Bound to carbonate $>$ Exchangeable $>\mathrm{Fe}-$ Mn Oxide. Zinc: $\mathrm{Fe}-\mathrm{Mn}$ Oxide $>$ Residual $>$ Organic $>$ Bound to carbonate $>$ Exchangeable. Copper: Residual $>\mathrm{Fe}-$ Mn Oxide $>$ Exchangeable $>$ Bound to carbonate $>$ Organic. The Toxic metals speciation of the soil samples indicate that the toxic metals were predominately in the non-residual fractions suggestive of input by anthropogenic sources and human activities due to military exercise and are readily available for plant uptake. This could pose serious health risk to the military personnel using the training period. Thus phyto-remediation technique which is cheap and non-destructive is recommended to be applied to remedy the affected toxic metals in the soil for its continual use as a military training ground and also preserve the soil fertility for continued agricultural use of the area when there is no military operation.
\end{abstract}

Index term - Toxic Metals, Speciation, Total metal Content, Military Activities and Shooting Range.

\section{INTRODUCTION}

Heavy metals are present in the environment and most of them are essential for animals and plants. They are natural constituent of rocks, soil, and sediments [1]. There is always a natural background level of metals originating from the parent rocks and these metals can occur in high concentration but in an inert form which, however, can be converted to

Published on December 23, 2020.

Jonathan Maduka Nwaedozie, Department of Chemistry, Nigerian Defence Academy, Nigeria.

Femi Emmanuel Awe, Department of Chemistry, Nigerian Defence Academy, Nigeria.

(e-mail: feawe @ nda.edu.ng). mobile and dangerous forms due to changing environmental conditions or changes in soil properties and this could lead to a "chemical time bomb" [2]. Heavy metals such as copper, nickel, chromium, and zinc are used in all kinds of practical objects and building materials without the users understanding its harmful risk. An origin of heavy metals may come from natural or anthropogenic a source, that is why it is very important to distinguish the individual species of heavy metals because some are more mobile, and some have a longer retention time in the soil environment [3].

While metals such as $\mathrm{Pb}, \mathrm{Hg}, \mathrm{Mn}, \mathrm{Cr}, \mathrm{Br}$, $\mathrm{Li}$, etc. are toxic even in small concentrations; the issue of toxicity is usually merely a matter of quantity, with the range varying for each element [4]. A heavy metal is not toxic per se; it is only considered toxic when its concentration exceeds a certain threshold (it is the dose that makes the effect) [5].

Some anthropogenic sources of toxic metals such as Arsenic, Cadmium, Chromium, Lead, Mercury and Nickel include the burning of coal and industrial sewage sludge, pesticides, fertilizer impurities, emissions from mining and smelting operations, military activities, wastewater from dyeing and chemical industries, lubricants and metallurgical activities [6]. Heavy metals do not degrade but remain in the environment for a long time even after the removal of the pollution source [7]. Once heavy metal concentrations surpass a certain threshold in soils, they tend to cause serious environmental problems due to their toxicity, nonbiodegradable properties, and widespread distribution [8].

Military activities are one of the anthropogenic sources of toxic metal contaminations to soil and tend to contaminate the soils without appropriate recovery of polluted soil [9]. Shooting ranges are characterized by shooting of bullets and deposit of explosives which releases toxic metals like lead $(\mathrm{Pb})$, Antimony (Sb), Copper (Cu), Nickel (Ni) and Zinc ( $\mathrm{Zn})$ [10]. Lead concentrations exceeding $10,000 \mathrm{mg} / \mathrm{kg}$ in soil are commonly reported at shooting ranges around the world. 60,000 tons per year in the United States, 800 tons annually in Denmark and 500 tons in Switzerland [11]. Grazing animals have also been confirmed to have ingested large quantities of these heavy metals from unrestricted shooting ranges, which have crops richly grown on such site leading to animal poisoning, death, and human sickness all over the world [12].

In order to combat these teeming challenges which are becoming persistent in all military shooting sites involving heavy metal deposit into the soil, the determination of the free

Ifeanyi Charles Aghanwa, Department of Chemistry, Nigerian Defence Academy, Nigeria. 
metal ion in soil solution becomes important [13]. Meanwhile, the concentration of heavy metals in soil solution plays a critical role in controlling the availability of ions to plants. The physiochemical properties of the soil are also considered such as the soil $\mathrm{pH}$, electro conductivity, clay content and organic matter content [14]. Total metal content of soils is useful for many geochemical applications but often the speciation (bioavailability) of these metals is more of an interest agriculturally in terms of what is biologically extractable and scientifically to researchers [15].

The use of sequential extraction procedure for environmental studies provides an important tool for the determination of the different chemical forms or ways of binding between trace metals and soil components [16]. This extraction enables us to associate the metals with one of the following geochemical phases which are the acid-soluble phase, reducible phase, oxidizable phase and the residual phase. This gives a clear indication of the metal reactivity, strength, and phase association of the metal in soil, sediments and water [17].

In Nigeria there are several shooting ranges and the concentrations of heavy metals in the soils of these shooting ranges have not been fully researched. Kwanar - Doya is one of the shooting sites in the Nigerian Army Military Training, Base Camp located in Kachia Local Government Area, Kaduna State. The Nigerian Army Base Camp, Table hill, Kachia, Kaduna State over the years, is been used as the field training exercise ground for military personnel.

The military training undergone at the exercise ground includes leadership and adventure training, practical map reading test, company level field training exercise, navigational training and field firing of weapons [18]. The objectives of this paper were to study some physico-chemical parameters, toxic metal content of the soil and its speciation. This research will also help provide vital information, which will be useful for future reference in shooting ranges research in Nigeria.

\section{MATERIALS AND METHOD}

\section{A. Sample Collection and Preparation}

Soil samples were collected from the Kwanar -Doya Shooting site in the Nigerian Army Base Camp military shooting range, Kachia Local Government, Kaduna State. A transect, $1000 \times 1000$ meters long was demarcated with a wheel-able measuring meter within the shooting areas and soil samples were collected within the measured areas. Surface soil samples were collected at the various sample areas from a surface level $(0-30 \mathrm{~cm}$ in depth) with a Soil auger [19]. Ten (10) Composite samples were collected in duplicates within the grid in the sampling location and stored in labelled polyethylene bags [20]. The collected samples were air-dried, grinded with a mortar and pestle and sieved with a $1 \mathrm{~mm}$ sieve into coarse and fine fraction sand thoroughly homogenized. This was then transferred into a plastic container for analysis [21].

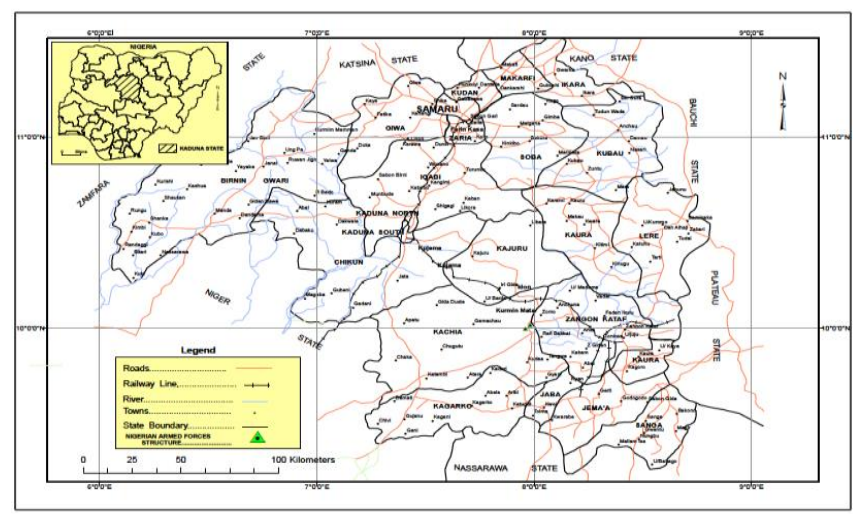

Fig. 1. The Map of Nigeria, showing Kaduna State and its Local Government Areas including Kachia Local Government Area (Source: Nigerian Defence Academy (NDA) Geography Department, Kaduna State).

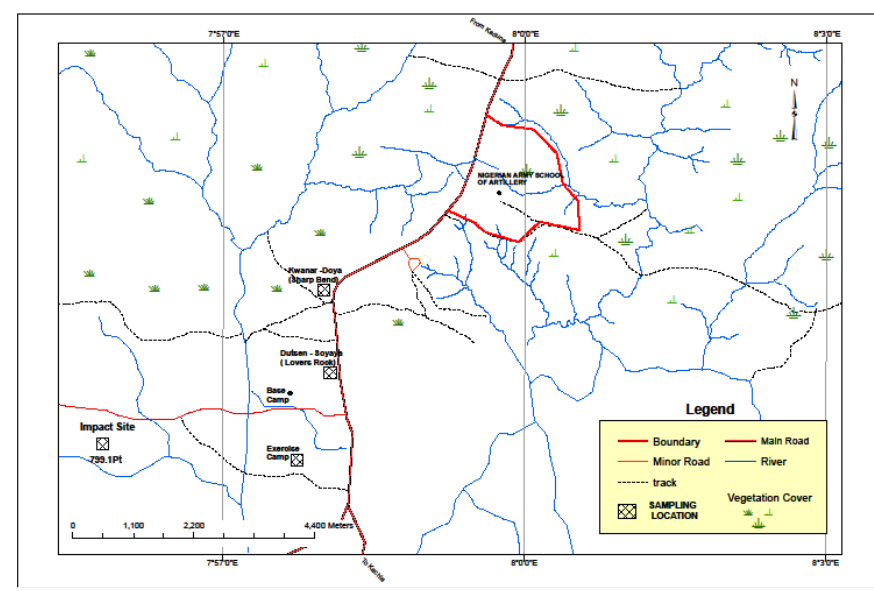

Fig. 2. The Map of the Nigeria Army Base Military Shooting Ranges in which the sampled shooting site is included in Kachia Local Government,

Kaduna State, Nigeria. (Source: Nigerian Defence Academy (NDA) Geography Department, Kaduna State).

\section{B. Method of Analysis}

\section{Soil pH Determination}

$20 \mathrm{~g}$ of the sample soil was weighed in duplicates into two $250 \mathrm{~cm}^{3}$ beakers. $50 \mathrm{~cm}^{3}$ of distilled water was added to the first and second set of beakers. $150 \mathrm{~cm}^{3}$ of $0.01 \mathrm{~m} \mathrm{CaCl}_{2}$ was added to the second set of beakers containing the soil solution and the two sets of beakers was stirred for 1 minute and left to stand for 15 minutes. Again, the mixture was stirred and left for another 15 minutes. While waiting for the last 15 minutes, the $\mathrm{pH}$ meter was standardised using different $\mathrm{pH}$ buffer solutions of $\mathrm{pH} \mathrm{4,7}$ and 9. After the last 15 minutes, the electrode of the $\mathrm{pH}$ meter was then inserted into the supernatant liquid to read the $\mathrm{pH}$ values. The $\mathrm{pH}$ reading in both water and calcium chloride was recorded [22].

\section{Soil Electrical Conductivity Determination}

$2 \mathrm{~g}$ of each air-dried sieved soil was weighed into a $250 \mathrm{~cm}^{3}$ conical flask and $20 \mathrm{~cm}^{3}$ of distilled water was added and the mixture stirred. The electrode of the conductivity meter was inserted into the supernatant liquid to read the value of the conductivity of the soil [23].

\section{Total Metal Content of the Soil Samples}

$2.0 \mathrm{~g}$ of pulverized soil sample was added in a $250 \mathrm{~cm}^{3}$ beaker and moistened with few drops of deionized water to prevent loss by spattering during digestion. The sample was digested with $10 \mathrm{ml}$ of concentrated $\mathrm{HNO}_{3}$ on a hotplate in a 
fume cupboard to volume of about $3 \mathrm{ml}$. The residues obtained was further digested with a mixture of concentrated acids containing $5 \mathrm{ml}$ each of concentrated $\mathrm{HCl}, \mathrm{HNO}_{3}$ and $\mathrm{HClO}_{4}$ at room temperature for 10 minutes until the solution final volume was about $5 \mathrm{ml}$ on a hot plate in fume cupboard. The digest was then allowed to cool and then filtered into a $100 \mathrm{ml}$ volumetric flask using Whatman No.40 filter paper and made up to the mark with distilled water. Then it was then transferred to a plastic sample bottles and analyzed with an Atomic Absorption Spectrophotometer (Thermo Scientific Model: iCE 3000 v1.30) for metal content analysis [24].

\section{Speciation Determination}

The sequential extraction method described by Tessier, A., Campbell, P. G. C and Bisson, M.1979) was adopted.

The Exchangeable fraction: $1.0 \mathrm{~g}$ of finely divided soil sample was added with $40 \mathrm{~cm}^{3}$ of $1 \mathrm{~mol}$ per $\mathrm{dm}^{3} \mathrm{MgCl}_{2}$ solution at $\mathrm{pH} 7.0$ and agitated using a Stuart flask shaker for 1 hour. The mixture was filtered and made up to $50 \mathrm{ml}$ volume with distilled water.

The Carbonate fraction: The sediment residue from exchangeable fraction was leached with $40 \mathrm{~cm}^{3}$ of $0.1 \mathrm{~mol}$ per $\mathrm{dm}^{3}$ of sodium acetate (adjusted to $\mathrm{pH} 5$ with $1 \mathrm{M}$ acetic acid) and agitated for 5 hr using a Stuart flask shaker.

The Easily Reducible fraction: The residue from carbonate fraction was added with $50 \mathrm{~cm}^{3}$ of $0.04 \mathrm{~mol}$ per $\mathrm{dm}^{3} \mathrm{NH}_{2} \mathrm{OH} . \mathrm{HCl}$ in $10 \mathrm{ml}$ of $25 \%$ (v/v) acetic acid and heated for $6 \mathrm{hr}$ in a thermostated water bath at a temperature of $96 \pm 2$ ${ }^{\circ} \mathrm{C}$ and the solution was stirred occasionally. The mixture was cooled, filtered, and made up to $50 \mathrm{ml}$ volume with distilled water and analyzed.

The Organic fraction: The residue from the easily reducible fraction was mixed with $15 \mathrm{~cm}^{3}$ of $0.02 \mathrm{~mol}$ per $\mathrm{dm}^{3}$ $\mathrm{HNO}_{3}$ and $25 \mathrm{~cm}^{3}$ of $30 \% \mathrm{H}_{2} \mathrm{O}_{2}$ and heated for $2 \mathrm{hr}$ at $85^{\circ} \mathrm{C}$ with intermittent agitation in a thermostated water bath. After cooling, $25 \mathrm{~cm}^{3}$ of $3.2 \mathrm{~mol}$ per $\mathrm{dm}^{3} \mathrm{CH}_{3} \mathrm{COONH}_{4}$ was added in $20 \%(\mathrm{v} / \mathrm{v})$ acetic acid and transferred to the mixture and agitated continuously at room temperature for 30 minutes. After each successive extraction, the sample was centrifuged at $4500 \mathrm{rpm}$ for 20 minutes. The supernatant was removed with a pipette and filtered with Whatman no 40 Filter paper.

The Residual Fraction: The residue from the organic fraction was washed with distilled water and the supernatant discarded. Then $5 \mathrm{ml}$ Concentrated $\mathrm{HF}$ and 10 mlConcentrated $\mathrm{HClO}_{4}$ was added to the residue and the sample digested. The digest was then filtered, and the filtrate analyzed for the residue bound metals ions. Each filtrate will be analyzed using Atomic Absorption Spectrophotometer (Thermo Scientific Model: iCE 3000 v1.30).

\section{RESUlTS AND DisCUSSION}

TABLE 1: THE PH READINGS OF THE SOIL SAMPLES

\begin{tabular}{cccc}
\hline $\begin{array}{c}\text { Serial } \\
\text { Number }\end{array}$ & Sample Location & $\begin{array}{c}\text { pH Readings } \\
\text { (Distilled } \\
\text { Water) }\end{array}$ & $\begin{array}{c}\text { pH Readings (Distilled } \\
\text { Water + Calcium } \\
\text { Chloride Solution) }\end{array}$ \\
\hline 1 & Kwanar-Doya A & 4.53 & 3.81 \\
2 & Kwanar-Doya B & 4.49 & 4.06 \\
3 & MEAN & 4.51 & 3.93 \\
4 & Control Point & 4.72 & 4.18 \\
\hline
\end{tabular}

TABLE 2: THE ELECTRO CONDUCTIVITY READINGS OF THE SOIL SAMPLES USING DISTILLED WATER

\begin{tabular}{ccc}
\hline Serial Number & Sample Location & $\begin{array}{c}\text { Electro Conductivity Reading } \\
(\mathrm{ms} / \mathrm{cm})\end{array}$ \\
\hline 1 & Kwanar-Doya A & 0.12 \\
2 & Kwanar-Doya B & 0.10 \\
& MEAN & 0.11 \\
3 & Control Point & 0.055 \\
\hline
\end{tabular}

TABLE 3: CONCENTRATIONS OF TOXIC METALS CONTENT (MG/KG) IN SOIL SAMPLE

\begin{tabular}{ccccccccc}
\hline Sample Location & Cobalt & Arsenic & Chromium & Nickel & Manganese & Lead & Zinc & Copper \\
\hline Kwanar-Doya A & 134.5 & 82 & 42.15 & 8.97 & 64.34 & 45.3 & 38.32 & 9.19 \\
Kwanar-Doya B & 190.5 & 528 & 56.49 & 17.93 & 91.90 & 36.3 & 19.57 & 6.3 \\
MEAN & 162.50 & 305 & 49.32 & 13.45 & 78.12 & 40.6 & 28.94 & 7.74 \\
Control & 18.42 & 35 & 36.48 & 3.677 & 165.92 & 33.29 & 55.5 & 12.40 \\
WHO & 19 & 20 & 50 & 20 & 0.04 & 10 & 250 & 2 \\
\hline
\end{tabular}

WHO values were obtained courtesy of [25].

TABLE 4: MOBILITY FACTOR (\%) OF THE TOXIC METALS IN THE SOIL SAMPLE

\begin{tabular}{cccccccccc}
\hline $\begin{array}{c}\text { Serial } \\
\text { Number }\end{array}$ & Sample Location & $\mathrm{Co} \%$ & $\mathrm{As} \%$ & $\mathrm{Cr} \%$ & $\mathrm{Ni} \%$ & $\begin{array}{c}\mathrm{Mn} \\
\%\end{array}$ & $\mathrm{~Pb} \%$ & $\mathrm{Zn} \%$ & $\mathrm{Cu} \%$ \\
\hline 1 & Kwanar - Doya Site & 45.21 & 58.26 & 73.64 & 77.85 & 48.15 & 30.11 & 70.48 & 48.32 \\
2 & Control Site & 23.30 & 19.10 & 33.40 & 12.67 & 42.41 & 23.86 & 47.58 & 58.04 \\
\hline
\end{tabular}

TABLE 5: DISTRIBUTION OF TOXIC METALS BOUNDS TO EACH FRACTION FROM SOIL SAMPLE

\begin{tabular}{ccccccccccc}
\hline S/N & Sample Location & Fractions & Co $\%$ & As $\%$ & Cr $\%$ & Ni $\%$ & Mn $\%$ & $\mathrm{~Pb} \%$ & $\mathrm{Zn} \%$ & $\mathrm{Cu} \%$ \\
\hline 1 & Kwanar - Doya Site & F1 & 14 & BDL & 23.85 & 23.79 & 7.08 & 10.03 & 2.36 & 12.40 \\
2 & Kwanar - Doya Site & F2 & 15.9 & 26.98 & 28.09 & 21.38 & 14.41 & 12.26 & 2.39 & 10.07 \\
3 & Kwanar - Doya Site & F3 & 14.23 & 31.27 & 21.69 & 32.66 & 26.65 & 7.80 & 65.72 & 25.83 \\
4 & Kwanar - Doya Site & F4 & 14.23 & 15.08 & 17.53 & 8.9 & 9.51 & 24.53 & 5.81 & 8.39 \\
5 & Kwanar - Doya Site & F5 & 40.55 & 26.64 & 8.82 & 13.20 & 42.33 & 45.35 & 23.69 & 43.28 \\
\hline
\end{tabular}

TABLE 6: DISTRIBUTION OF TOXIC METALS BOUNDS TO EACH FRACTION FROM SOIL SAMPLES FROM THE CONTROL SITE

\begin{tabular}{ccccccccccc}
\hline S/N & $\begin{array}{c}\text { Sample } \\
\text { Locations }\end{array}$ & $\mathrm{F}$ & $\mathrm{Co} \%$ & $\mathrm{As} \%$ & $\mathrm{Cr} \%$ & $\mathrm{Ni} \%$ & $\mathrm{Mn} \%$ & $\mathrm{~Pb} \%$ & $\mathrm{Zn} \%$ & $\mathrm{Cu} \%$ \\
\hline 1 & Control Site & $\mathrm{F} 1$ & 11.40 & 9.97 & 8.01 & 0.98 & 20.79 & 13.83 & 17.65 & 32.16 \\
2 & Control Site & F2 & 5.55 & 5.12 & 8.23 & 2.53 & 14.18 & 5.15 & 20.71 & 0.69 \\
3 & Control Site & F3 & 6.35 & 4.04 & 17.15 & 9.15 & 7.34 & 4.88 & 9.22 & 25.17 \\
4 & Control Site & F4 & 58.05 & 64.38 & 47.21 & 35.21 & 31.24 & 59.31 & 28.72 & 38.46 \\
5 & Control Site & F5 & 18.64 & 16.52 & 19.37 & 52.11 & 26.44 & 16.81 & 23.69 & 34.96 \\
\hline
\end{tabular}


Note: F1 and F2 represent the Exchangeable fraction and Carbonate Fraction. F3 and F4 represent the Easily Reducible Fraction and Organic Fraction. F5 represents Residual Fraction in the Sequential Extraction Procedure.

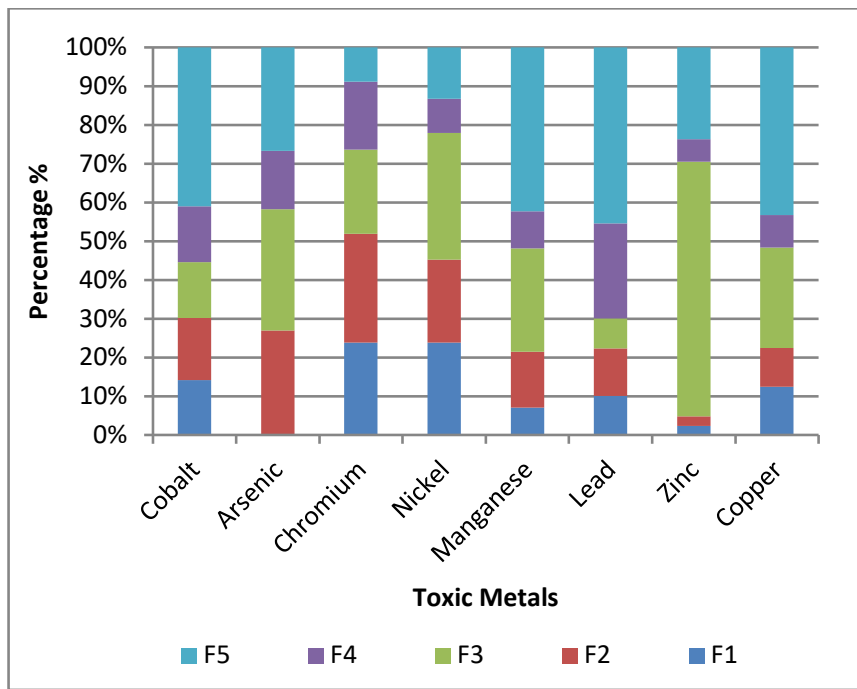

Fig. 3. Partition of toxic metals into different fractions in the kwanar-doya soil.

\section{A. Physico-chemical Parameters ( $p H$ and Electro Conductivity)}

Analysis of the soil samples revealed that the electro conductivity value was very low in the Kwanar-Doya shooting site, which also corresponds with the low values recorded at the control site, as displayed in Table 2. These values recorded at both sampled sites were below $200 \mu \mathrm{s} / \mathrm{cm}$ $(0.2 \mathrm{~ms} / \mathrm{cm})$. This indicates that the soil does not have enough nutrients available to the plants and could perhaps show a sterile soil with little microbial activity [26]. It was reported that decreased conductivity in soil may be attributed to high amount of metal substances in the soil [25]. Similarly, it was also suggested that increase in the concentration of some soluble salts in the soil could be as result of anthropogenic sources which could lead to increase in the electro conductivity of the soil [27]. The low electro-conductivity value observed in the soil could also be associated with its inability to conduct electric current as high electroconductivity value were a good indicator for the presence of soluble substances such as potassium, chlorides, sodium, and sulphates [28]. The low electro conductivity values recorded at the Kwanar-Doya shooting site could not be related to the shooting activities, which takes place at the site; as the control site also had a low electro conductivity value as observed.

Low $\mathrm{pH}$ values were also recorded in the sampled site and the control site as displayed in Table 1 . The $\mathrm{pH}$ values were below the neutral $\mathrm{pH}$ value of 7 , indicating that the soils in both the Kwanar-Doya shooting site and the control site were acidic. A similar report was obtained in the soils of Kachia and the $\mathrm{pH}$ values recorded in his research showed that the soils were also acidic [29]. The acidity of the soil at the Kwanar-Doya shooting site could not be related to the shooting activities going there, as the control site had a low $\mathrm{pH}$ value with no shooting activity observed there.

\section{B. Toxic Metal Concentrations}

Results showed that the toxic metals concentrations in the Kwanar-Doya shooting soil were higher in the shooting range than the control site. According to [10] military activities such as shooting were responsible for the large deposit of toxic metals in the soils of all shooting sites observed in her research. It was also reported similar occurrence of toxic metal deposit especially components of bullets such as lead and nickel [11].

High copper concentrations were recorded in the control site as compared to the Kwanar-Doya site as displayed in Table 3. The values obtained from both sites were above the WHO permissible limit for copper in soil. The high content of copper in the control may have resulted from the use of copper fertilizer [30] as the control site is known to be an active farmland. The copper content in the shooting site can be related to the shooting activities undergoing there as there were no observed farming activities at the shooting site. This is rather much as compared to the values obtained at the Kwanar-Doya shooting site, but its presence is a confirmation of the shooting activity as its prime source in the soil.

Lead concentration in both sampled soils was higher than the WHO values recommended for toxic metals in soil. The lead value for Kwanar-Doya shooting range was higher than the control sites as observed in Table 3.3. The value obtained at the shooting sites tends to correlate with some values in the lead content obtained by [10] in military training areas in one division, Kaduna Nigeria. The amount of lead recorded at the control site could not be attributed to any shooting range activities as the Kwanar-Doya shooting site. The presence of lead could either be as a result of other anthropogenic source such as the use ofpesticides and fertilizers [25] by the farmers, as there were no observed metallic producing industries at the site. The harmful effects of lead metal to humans are damage to kidneys, nervous system, learning ability, ability to synthesize protein, and nerve and red blood cells.

Chromium values at the shooting site were in the exact threshold limit of chromium metals in soil as recommended by W.H.O. The chromium content in the shooting site was higher than the chromium content in the control site as displayed in Table 3.3. The presence of chromium metal to the point of it being in the same limit as the recommended value showed that, its deposition was as a result of shooting activities in the shooting range. The control site had a chromium concentration that was below the recommended value but still poses as a serious threat in the future; as its increase could be absorbed by the crops been grown at the farm land. This could be as result of other anthropogenic factors excluding military input. The presence of chromium in the control site could also be as result of weathering of the soil bedrock or other anthropogenic source except from shooting activity and metal production industries. Chromium has been found to be a very important component in weaponry fabrications of arms and thus its presence in all military sites to be unarguable due to its use. Although chromium toxicity is the environment is relatively unpopular, it still presents some risk to the human health, since chromium can be accumulated in the liver, dorsal spine, hair, nails and placenta [31].

Nickel concentration in this study was below the W.H.O permissible value for nickel metal in soil. The obtained at the 
Kwanar-Doya shooting site was above the amount recorded in the control site. The increase in the value of nickel concentration in the shooting site can be related to shooting activities been performed by military personnel. Nickel directly forms a component of $0.5 \%$ in bullet making [32], [33] also reported that most of the Swiss military shooting sites were heavily toxic with a mean of $917 \mathrm{mg} / \mathrm{kg}$ making the soil very dangerous for animals to consume plants grown on the soil. The values of Nickel obtained at the shooting site were lesser than the values recorded by the authors above. This is good for effective monitoring and available remediation, so as effectively curb its toxicity in the soil before its values reaches a much higher quantity as reported [10]. The nickel content of $3.67 \mathrm{mg} / \mathrm{kg}$ in the soil of the control site may be as result of the weathering of the bedrock in that sampling area. Since nickel cannot be deposited by any agricultural practices except through metallic sources [13].

Zinc concentrations for the shooting site and the control site were below the WHO permissible limit for Zinc in soil as displayed in Table 3. Zinc in the control site tends to be higher in value as result of the application of agrochemicals in the farmland. The amounts of extractable zinc in the shooting site were smaller than the control site.

\subsection{Sequential Extraction}

Fractionation of total metal content may give indications of the origin of the metals. High level in the exchangeable, acid soluble and reducible fraction may indicate pollution from anthropogenic origin [35]. The results of the distribution of the toxic metals are displayed in Table 5, 6 and Fig. 3. While the mobility factor results of the toxic metals were displayed in Table 4.

Cobalt: The potential bioavailability of the cobalt metal in the shooting site soil were as follows in this order: Residual fraction $(40.50 \%)>$ Bound to carbonate $(15.90 \%)>$ Exchangeable $(14.30 \%)>\mathrm{Fe}-\mathrm{Mn}$ Oxide $(14.23 \%)>$ Organic $(14.23 \%)$. This clearly shows that the bulk of the cobalt metal which was distributed in the residual fraction and the least at the organic fraction. The result as displayed in Table 3.5-3.6 shows that most of the cobalt metals are in the non-active forms and thus that percentage in the residual and organic fraction poses no serious threat to the plants and the outer environment. The mobility factor of cobalt as displayed in Table 4 is $45.21 \%$, thereby making the metal to be readily bioavailable as a result of the combined fractions in the bioavailable regions.

Chromium: The order of bioavailability of chromium metal in the shooting site is as follows: Bound to carbonate $(28.09 \%)>$ Exchangeable $(23.85 \%)>\mathrm{Fe}-\mathrm{Mn}$ Oxide $(21.69 \%)>$ Organic $(17.53 \%)>$ Residual $(8.82 \%)$. The distribution of chromium shows that the metal is more represented in the bioavailable fractions and thus its origin could be anthropogenic. The mobility factor of the metal in the soil is $73.64 \%$, thereby making the metal more bioavailable to the plants and animals.

Nickel: Nickel metal in the shooting site soil tends to have a higher mobility factor of $77.85 \%$, making the metal more bioavailable to the plant, although being lower than the W.H.O value for nickel in soil. The mobility of nickel shows that the plants might absorb the metals very quickly in a short period of time. The order of bioavailability is as follows: Fe - Mn Oxide (32.66\%) > Exchangeable (23.79\%) > Bound to carbonate $(21.38 \%)>$ Residual $(13.20 \%)>$ Organic $(8.9 \%)$. The bioavailable fractions of the shooting site soil had nickel highly distributed in it and thus be more reactive to the soil solution in the shooting site.

Arsenic: The arsenic value obtained from the shooting site soil was far above the WHO permissible limit and the mobility factor of arsenic was $58.26 \%$. This made the mobile phase appreciable and thus the rate of the metals to reach the outer environment fast. The order of the distribution of arsenic in the different fractions is as follows: $\mathrm{Fe}-\mathrm{Mn}$ Oxide $(31.27 \%)>$ Bound to carbonate $(26.98 \%)>$ Residual $(26.64 \%)>$ Organic $(15.08 \%)>$ Exchangeable $(\mathrm{BDL})$. These values confirm the presence of arsenic metal for easy uptake by the plant and animals.

Manganese: The order of distribution of manganese metal in the shooting site soil is as follows: Residual $(42.33 \%)>\mathrm{Fe}$ - Mn Oxide $(26.65 \%)>$ Bound to carbonate $(14.41 \%)>$ Organic $(9.51 \%)$. The result shows that manganese was highly distributed in the residual fraction and the least distribution occurring at the organic fraction. The mobility factor of manganese in the soil was $48.15 \%$, thereby making it bioavailable to the plants and animals.

Lead: The total content of lead in the shooting range soil was above the WHO permissible limit, making it a huge concern for the existing environment. The mobile phase of lead in the soil was $30.11 \%$, thereby making it readily available for uptake by plants and animals. The potential bioavailability of lead is as follows: Residual (45.35\%) > Organic $(24.53 \%)>$ Bound to carbonate $(12.26 \%)>$ Exchangeable $(10.03 \%)>\mathrm{Fe}-\mathrm{Mn}$ Oxide (7.80). the nonreactive fraction had the highest distribution of lead at the shooting site soil, while the least distribution occurred at the reducible fraction.

Zinc: The value of zinc in the total toxic metal content in the shooting range soil was below the WHO permissible limit. The percentage of metal in the mobile factor is $70.8 \%$ making it readily available for plant uptake. The order of bioavailability is as follows: $\mathrm{Fe}-\mathrm{Mn}$ Oxide > Residual > Organic $>$ Bound to carbonate $>$ Exchangeable. This result shows that the soil was highly distributed in the non-reactive fractions and little reactive forms of zinc were available for the outer environment.

Copper: The potential bioavailability of the copper metal in the shooting range soil are in the following order: Residual $(43.28 \%)>\mathrm{Fe}-\mathrm{Mn}$ Oxide $(25.83 \%)>$ Exchangeable $(12.40 \%)>$ Bound to carbonate $(10.07 \%)>$ Organic $(8.39 \%)$. Copper was evenly distributed between the bioavailable fractions and the non-reactive fractions as displayed in Figure 1. The mobility factor of copper in the sampled soil was $48.32 \%$, thereby making it more bioavailable to the plants for absorption.

\section{CONCLUSION}

This study has revealed that the soil sample obtained from the Kwanar-Doya shooting site of the Nigerian Army Military Training Ground, camp highland, Kachia, Kaduna State was acidic and had little nutrients in the soil. From the total toxic metals in the soil, it can be seen the concentration of the metals were above the WHO permissible limit for toxic metals except for zinc and Nickel. Its distribution showed that 
most of the metals was highly distributed in the bioavailable fractions and had high mobility factors in all the toxic metals in the soil, making them readily available for plants uptake. Phyto -remediation of affected soil should be affected as it will help reduce the deposit of these toxic metals in the soil and also preserve the environment and the site. The continual use of the site should be done with caution and the use of agricultural activities should be minimized to avoid bioaccumulation and eventual transfer to humans.

\section{ACKNOWLEDGMENTS}

The authors wish to acknowledge the sponsorship of the project by the Tartary Eduction Fund (TertFund) for the 2017/18 session. The great assistance of the Commandant Nigerian Defence Academy and the authorities of Defence Industries Cooperation of Nigeria Kaduna in the use of their analytical instruments is highly appreciated.

\section{REFERENCES}

[1] Ideriah, T. J. K., Ikpe, F. N and Nwanjoku, F.N. (2013). Distribution and Speciation of Heavy Metals in Crude oil Contaminated Soil from Niger - Delta, Nigeria. World Environment; 3(1): 18-28.

[2] Stigliani, W. M. (1993). Overview of the Chemical time bomb problem in Europe. In: Meulen, G.R.B., Stigliani, W.M., Salomons, W., Bridges, E.M., Imeson, A. C. (eds): chemical time bombs. In: Proceedings of the European State of the art conference on delayed effects of chemicals in soils and sediment. $2^{\text {nd }}-5^{\text {th }}$ September 1992 , Veldhoven, 13-29.

[3] Sposito, G. 2008. The Chemistry of Soils. Oxford University Press. New York.

[4] Zovko, M and Romic, M. (2011). Soil contamination by trace metals: Geochemical behaviour as an element of risk assessment, earth and environmental sciences, Dr. Imran Ahmad Dar (Ed). ISSB:978-953307-468-9.

[5] Appenroth, K.J., Sherameti, I and Varma, A. (2010). Soil Heavy metals. Soil Biology Eds, Vol 19. Springer-Verlag, Berlin Heidelberg.

[6] Shreene, T. (2010). Mobility and Transport of Heavy Metals in polluted soil environment. Biological Forum; 2(2):112-121.

[7] Adeyi, A.A and Torto, N. (2014). Profiling Heavy metal Distribution and Contamination Soil of Old Power Generation Station in Lagos, Nigeria. American Journal of Science and Technology; 1(1):1-10.

[8] Wang, J., Lui, C., Huang, C., Cao, L., Yang, J., Cai, W., Fang, H and Peng, X. (2014). Speciation of metals and Assessment of contamination in Surface Sediments from Daya Bay, South China Sea. Sustainability; 6: $9096-9113$.

[9] Greiciute, K., Juozulynas, A., surkiene, G and Valeikiene, V. (2007). Research on Soil Disturbance and Pollution with Heavy Metals in Military Grounds, Geologija. Vilnius. 57: 14-20.

[10] Nwaedozie, G., Mohammed, Y., Faruruwa, D and Nwaedozie, J. (2013). Environmental Impact of Toxic Metal Load in Some Military Training Areas within the One Division of Nigeria Army, Kaduna, Nigeria. International Journal of Academic Research inBusiness andSocial Science; 3(2).

[11] Sanderson, P., Bolan, N., Bowman, M and Naidu, R. (2010). Distribution and Availability of Metal Contaminants in Shooting Range soils around Australia. $19^{\text {th }}$ World Congress of Soil Science, Brisbane, Australia.

[12] Corinne, R. (2016). Contamination of Shooting Ranges. Culled from www. lead.org.au. Accessed on the $10^{\text {th }}$ February 2016.

[13] Ene, A., Popescu, I. V and Stihi. C. (2009). Application of Protein Induced X-ray Emission Technique in Materials and Environmental Science. Oridius Unn. Ann. Chem; 20(1): 35.

[14] Srikantaswamy, S., Shivakumar, D., Kiran, M.B and Sreenivasa, S. (2012). Speciation and Geochemical Behaviour of Heavy Metals in Industrial Area soil of Mysore city, India. Journal of Environmental Protection; 3: 1384 - 1392

[15] Ashraf, M.A., Maah, M.J and Yosoff, I. (2011). Chemical Speciation and Potential mobility of Heavy metls in the foil of former Tin Mining catchment. The Scientific World Journal; 11.

[16] Rauret, G., Lopez-Sanchez, J. F., Sahuquillo, A., Rubio, R., Davidson, C., Ure, A and Quevauviller, P. (1999). Improvement of the BCR Three step Sequential Extraction Procedure prior to the Certification of new sediment and soil reference materials.J. Environ. Monit; 1: 57-61.

[17] Sakar, S.K., Faras, P.J.C., Rakshit, O and Satpathy, K.K. (2012). Geochemical Speciation and Risk Assessment of Heavy Metals in Soil and Sediment. Journal of EnvironmentalMonitoring and Assessment; 184(2):7561 - 7577.

[18] Ahmadu-Saka, M, (2015). NDA: Turning Cadets into Officers. The Daily Trust. Culled from www.dailytrust.com.ng/daily/index.php/feature/59585-nda-turningcadets-into-officers.html.Posted on the $10^{\text {th }} \mathrm{July}, 2015$. Accessed on the $3^{\text {rd }}$ December, 2015.

[19] Adaikpoh, E.O. (2013). Distribution and Enrichment of Heavy Metals in Soils from Waste Dump sites within Imoru and Environs, SouthWest Nigeria. Journal of Environment and Earth Science; 3(4).

[20] Okunlola, O.J; Uzariu, A and Ndukwe, G. (2007). Level of Trace Metals in Soil and Vegetation along Major and Minor Roads in the Metropolitan City of Kaduna State. African Journal of Biotechnology; 6(14): 1703-1709

[21] Salah, E., Turki, A and Noori, S. (2013). Heavy Metals Concentration in Urban Soils of Fallujah City, Iraq. Journal of Environmental and Earth Science; 3(11).

[22] Joan, D. W. (1999). Chemical Analysis of Soils adapted from LaMotte Test Kit. Journal ofChemical Education. Retrieved from www.colleges.org/sciencereform

[23] Inuwa, M., Abdulrahman, F.W., Birnin Yauri, U.A., and Ibrahim, S.A. (2007). Analytical Assessment of some Trace Metals in Soils around the Major Industrial areas of Northwestern Nigeria. Trends in Applied Sciences Research; 2:515-521.

[24] Majolagbe, A.O., Yusuf, K.A and Duru, A.E. (2013). Trace Metals Characteristics in Environmental Media: A Case Study of Cement Production Area, Ewekoro, South West, Nigeria. European Scientific Journal. Special Edition; 3 .

[25] Ojiako, E.N and Aduaka, P.C. (2015). Effects of Heavy metals in Agricultural soils of Dunukofia Local Government Area of Anambra State, Nigeria. International Journal ofResearch Studies in Science, Engineering and Technology; 2(4): 28-31.

[26] Agriculture Solutions. (2015). The Why and How to testing the Electroconductivity of Soils. Culled from www.agriculture solutions.com/resources/92/topic.html. Accessed on the $22^{\text {nd }}$ January, 2016.

[27] Akpoveta, O.V., Osakwe, S.A., Okoh, B.E and Otuya, B.O. (2010). Physico-chemical characteristics and level of some heavy metals in soils around metal scrap dumps in some parts of Delta State, Nigeria. J. Appl.Sci.Environ. Manage; 14(4): 57-60.

[28] Ruqia, N., Muslim, K; Masab, M., Hammed, U.R., Naveed, U.R. Surryab, S., Nosheen, A., Sajed, M., Mohib, U., Rafeeq, M and Zeenat, S. (2015). Accumulation of Heavy Metals (Ni, Cu, Cd, Cr, Pb, Zn, Fe) in the Soil, Water and Plants and Analysis of Physico-Chemical Parameters of Soil and Water collected from Tanda Dam Kohat Journal of Pharmaceuticals Sciences and Research; 7(3):89-97.

[29] Mohammed, S. S., Yahaya, H. K and Jamilu, H. (2013). Bioavailability of Zinc in Guinea Corn and Soils collected from Selected Agricultural areas of Kaduna Metropolis, Nigeria. International Journal of Research in Chemistry and Environment; 3(1): 246 - 252

[30] Spectrum Analytic. (2016). Copper. Culled from www.spectrumanalytic.com/support/library/ ff/ cu_basics/ html. Accessed on the $28^{\text {th }}$ March, 2016.

[31] Reyes - Gutierrez, L.R., Romeo - Guzman, E.T., Cabral - Prieto, A and Rodriquez - Castilo, R. (2007). Characterization of Chromium in Contaminated Soil studied by SEM, EDS, XRD and Mossbauer Spectroscopy. J. Miner. Mater. Characterization Eng; 7(1): 59 - 70.

[32] Robinson, B.H., Bischofberger, S., Stoll, A., Schroer, D., Furrer, G., Roulier, S., Grhenwald, A., Attinger, W and Schulim, R. (2008). Plant uptake of Trace Elements on a Swiss Military Shooting Range: uptake pathways and Land Management Implications. Environmental Pollution; 153: 668 - 676 .

[33] Rooney, C.P., McLaren, R.G., Cresswell, R.J. (1999). Distribution and phytoavailability of lead in a soil contaminated with lead shot. Water, Air and Soil Pollution; 116: 535 -548.

[34] Odoh, R., Agbayi, E. B., Kagbu, J. and Thomas, S. A (2011). Heavy Metal Speciation in Agricultural Farmland in Some Selected Local Government Areas of Benue State, Nigeria. Arch. Appl. Sci. Res. 3 (3); 560-573. 